\title{
Analysis of the Housing Market with the Roles of Private House-Builders on the Middle-Income Group Segment in Yangon, Myanmar
}

\author{
${ }^{*}$ Myint Naing ${ }^{1,2}$ and Vilas Nitivattananon ${ }^{2}$
}

Published online: 15 July 2020

To cite this article: Myint Naing and Vilas Nitivattananon (2020). Analysis of the housing market with the roles of private housebuilders on the middle-income group segment in Yangon, Myanmar. Journal of Construction in Developing Countries, 25(1): 83-108. https://doi.org/10.21315/jcdc2020.25.1.5.

To link to this article: https://doi.org/10.21315/jcdc2020.25.1.5

\begin{abstract}
Yangon is the prime city of a low-urbanised Myanmar where housing shortages have been occurring with the acute insufficient supply by private-house builders. In this study, the main objectives are to analyse the urban housing market in Yangon and to explore the dominant conditions and constraints that hinder the private house-builders' role on the middle-income group (MIG) segment. A mixed research method, including qualitative and quantitative approaches, is applied to analyse data obtained from both primary and secondary sources. The results show that Yangon housing market is a poorly functioning market with fragile key players such as government, financial institutions and private house-builders. This article shed light upon the current housing situation as a distorted market with a large unmet demand for urban housing under five dominant conditions. While current housing condition is inadequate for Yangonites, Yangon will be mega city due to rapid urbanisation during a few decades and immense housing shortage will be one of the major urban agendas in future. Being under transition period, Myanmar government should facilitate the private sector as a key driver of urban housing and they should set up actionable policy and plans which can overcome key constraints of private house-builders in line with enabling approach as current global housing policy paradigm in the developing countries. Among the 25 constraints, seven are key constraints mainly on the underdeveloped financial sector, weak business sector and high bureaucratic cost.
\end{abstract}

Keywords: Developing countries, Dominant conditions, Key constraints, Middle-income group (MIG), Private house-builders

\section{INTRODUCTION}

Unarguably, housing is a basic human necessity alongside food and clothing. It is also strongly influential on the daily life of people, their health, security and wellbeing for both present and future generations (Golubchikov and Badyina, 2012). Urban housing is one of the most challenging agendas for developing countries because it is heterogeneous, complex and distinct from other common goods due to its significant features such as immobility, durability, expensiveness and high moving cost (Sullivan, 2007). The middle-class in Asia has been emerging by urbanisation with rapid economic growth and the spending power of this social class can raise demand on the middle-cost urban housing market (Yap, 2016). According to international studies, private house-builders can potentially have

\footnotetext{
'Department of Urban and Housing Development, Ministry of Construction, MYANMAR ${ }^{2}$ School of Environment, Resources and Development, Asian Institute of Technology, THAILAND "Corresponding author: myintnaing.duhd@gmail.com
} 
a vital role in the provision of affordable housing for the middle and low-income group in urban housing with effective government support (Witwer, 2007).

In 2011, the elected democratic government (Union Solidarity and Development Party [USDP]) committed Myanmar to pursue integration with the global community through a series of political and economic reforms (Government of Myanmar, 2013). Although the government did not prioritise urban development, regional authorities have raised urban housing as a key challenge among urban issues in Myanmar especially Yangon, a prime city of Myanmar (Ministry of National Planning and Economic Development [MNPED], 2015). Due to the insufficient provision of formal housing supply across the market spectrum to match rising demand, housing shortages have increased sharply since the late 20th century in Yangon (Urban Research and Development Institute, 2013).

Currently, private house-builders commonly focus on luxury and high-cost market housing for profit maximisation and the government usually concentrates on low-cost housing for social benefit in Yangon. Therefore, the main objective of the study is to define key constraints of private house-builders' role on the middleincome group's (MIG) market segment. Moreover, the current situation of the urban housing market and the dominant conditions for hindering on urban housing in Yangon were also explored.

\section{LITERATURE REVIEW}

Housing is the necessity for human survival and composed physically of five basic elements, namely land, finance, infrastructure, labour and materials (Leung, 2004; Malpezzi, 1999). While the housing market is theoretically driven by supply and demand equilibrium, private house-builders are one of the key players for housing market stability alongside central and regional governments, financial institutions and buyers (Wang and Zhang, 2014).

\section{Role and Constraints of the Private Sector in Housing Market}

A well-functioning housing market is harmonised and continuously operated with close links between suppliers (public, co-operative or private), occupiers via either rental or purchase and financial institutions on both the supply and demand side, under monitoring and regulation by central and local governments (Shuid, 2015). Among the various producers, private house-builder is the main producer in the housing industry. There is an unarguable message that the private sector has been more efficient and reliable on housing delivery than the public sector (Sengupta, 2006). The favourable role of the private sector is based on the perception of profitdriven efficiency and effectiveness, compared to the corruption and inefficiency of the public sector (Ismail, 2013). Moreover, evidence suggests that promoting the private sector, with the collaboration of all stakeholders (especially the government role) can promote the development of a sustainable housing sector, as the ideal system of housing delivery in developing countries (Sivam et al., 2001). During the late 20th century, the global paradigm shift of housing policy concentrated on the market-driven from direct public housing provision to the enablement of private shelter initiatives and production (Ogu and Ogbuozobe, 2001). "Enabling Approach" led by the World Bank has dominated and acknowledged by policymakers and governments especially in the developing countries. This global housing policy 
paradigm advises government to abandon their earlier role as producers of housing (previous global housing policy paradigms as "Public Housing Approach" in the 1950s and "Self-Help Approach" in 1970s) and encourages to adopt an enabling role of managing the housing sector as a whole (World Bank, 1993). This approach generally focuses on expanding the role of the market and overcome largely external constraints to a more efficient market mechanism.

There are many studies on constraints of the housing sector especially on supply constraints which are easily measurable. For developed countries, supply constraint is likely to impact on variation for housing price and has been subject to criticism by many researchers (Paciorek, 2011; Aura and Davidoff, 2006; Hilber and Vermeulen, 2012). However, supply constraints on the poor functioning market for the developing countries which have significantly occurred not only price fluctuation but also an expansion of informal housing (Keivani and Werna, 2001).

There are many developing countries such as Nigeria, Iran and South Africa who have been pursuing the enabling housing market strategies to overcome the salient issues or the constraints of the housing sector (Ibem, 2010). According to the previous experiences from Nigeria, although the private sector has played a key role, it has failed to provide affordable housing to the MIG and low-income group (LIG) due to some constraints, such as inadequate finance, high cost of building materials, inefficient land-use policy, shortage of residential infrastructure and ineffective institutional regulations (Eni and Danson, 2014; Ogu and Ogbuozobe, 2001; Buckley, Faulk and Olajide, 1997).

While Nigeria tried to engage in a set of comprehensive policy measures for developing the housing sector, Iran's approach was only against strong government land management with Public-Private Partnership (PPP) schemes. The Iranian experience has demonstrated that government intervention can provide a rich source of urban land resources for housing and increase the capacity for public-private joint venture schemes. It can be a more effective mechanism for developing private sector role rather than leaving the entire process to the market (Keivani, Mattingly and Majedi, 2005).

Similarly, the Mandela government for South Africa had been adopted enabling housing market strategies and set out an ambitious housing policy to ease the unenviable housing record after the demise of apartheid. While their policy generally implemented the detail list of the "do's" and "don'ts" of the World Bank's instruments, they deeply addressed on two leading demand side constraints, the rationalisation of subsidy finance and the integration of financial institutions and development of a mortgage market (Jones and Datta, 2000).

Even though Enabling Approach is a current global housing policy paradigm, it does not provide a route map to policymakers as to how to formulate policy and indicate how these principles are to be translated into concrete policy reform (Jones and Datta, 2000). While the countries had commonly pursued to enabling market approach, practical strategies can differ which based on the respective situation of each country. The World Bank's instruments and selected countries' strategies are as stated in Table 1. 
Table 1. Comparison between the World Bank's Instruments and Selected Countries' Focusing Strategies

\begin{tabular}{|c|c|c|c|c|}
\hline $\begin{array}{l}\text { The World Bank's } \\
\text { Instruments }\end{array}$ & $\begin{array}{l}\text { Nigeria's } \\
\text { Focusing } \\
\text { Strategies }\end{array}$ & $\begin{array}{l}\text { Iran's } \\
\text { Focusing } \\
\text { Strategies }\end{array}$ & $\begin{array}{l}\text { South Africa's } \\
\text { Focusing } \\
\text { Strategies }\end{array}$ & Remarks \\
\hline $\begin{array}{l}\text { Develop property } \\
\text { rights }\end{array}$ & - & - & - & $\begin{array}{l}\text { Demand } \\
\text { side }\end{array}$ \\
\hline $\begin{array}{l}\text { Develop mortgage } \\
\text { finance }\end{array}$ & $\begin{array}{l}\text { Housing } \\
\text { finance }\end{array}$ & - & $\begin{array}{c}\text { Development } \\
\text { of a mortgage } \\
\text { market }\end{array}$ & \\
\hline Rationalise subsidies & - & - & $\begin{array}{l}\text { Rationalisation } \\
\text { of subsidy } \\
\text { finance }\end{array}$ & \\
\hline Provide infrastructure & $\begin{array}{l}\text { Residential } \\
\text { infrastructure }\end{array}$ & - & - & Supply-side \\
\hline $\begin{array}{l}\text { Regulate land and } \\
\text { housing development }\end{array}$ & Access to land & $\begin{array}{c}\text { Strong } \\
\text { government } \\
\text { land } \\
\text { management }\end{array}$ & - & \\
\hline $\begin{array}{l}\text { Organise the building } \\
\text { industry }\end{array}$ & $\begin{array}{l}\text { Building } \\
\text { materials }\end{array}$ & - & - & \\
\hline $\begin{array}{l}\text { Develop a policy and } \\
\text { institutional framework }\end{array}$ & $\begin{array}{l}\text { Institutional } \\
\text { regulation }\end{array}$ & $\begin{array}{l}\text { Capacity for } \\
\text { public-private } \\
\text { venture } \\
\text { schemes }\end{array}$ & - & $\begin{array}{l}\text { Institutional } \\
\text { framework }\end{array}$ \\
\hline
\end{tabular}

Sources: World Bank (1993), Ogu and Ogbuozobe (2001), Keivani, Mattingly and Majedi (2005) and Jones and Datta (2000)

\section{Urbanisation in Myanmar}

While the majority of the world population resides in urban areas nowadays, Myanmar can be regarded as a low urbanised country, "Burma (Myanmar) is still a predominantly rural country" as stated by Leonard (1985). In the early 21 st century, a hint of rapid urbanisation can be seen in Myanmar especially in major cities. The economic pattern has been gradually changing from agro-based economy to industrial and services-based economy. For instance, national gross domestic product (GDP) was shared into $41.9 \%$ for services, $30.9 \%$ of the industry and $27.1 \%$ for agriculture in 2018 (World Bank, 2018). Moreover, some dominant factors have fueled on rural-urban migration especially on the instability of the agriculture sector by climate change, natural disasters and insurgencies on border areas. It was expected that the urban population of Myanmar will grow from 15.4 million in 2014 to about 20.4 million in 2030 (Department of Urban and Housing Development [DUHD] and United Nations Human Settlements Programme [UN-Habitat], 2017).

According to the experiences from other primate cities, managing rapid urbanisation is very complex and only a few cities have executed thoroughly. The rapid growth of a city cannot avoid tremendous urban problems including immense housing shortage (Dobermann, 2016). In the current, urban challenges including urban housing are inevitable agendas for Myanmar development pathway. 
Therefore, DUHD has been trying to set up officially National Urban Policy supported by international development partners mainly UN-Habitat (DUHD and UN-Habitat, 2017).

Myanmar urban policy framework is mainly founded on a preponderance of the Tri-Polar development corridor, Yangon-Nay Pyi Taw-Mandalay, as geographical and historical favour alongside the Irrawaddy River civilisation. Moreover, while the overall process of urbanisation in Myanmar is still in its early stage, rapid urban growth of two major cities as Yangon and Mandalay have been started by a various push and pull factors especially the development of the sector of low-skilled manufacturing activities and substantial domestic and foreign investments (DUHD, 2018). Projection of urbanisation in Myanmar shows that number of residents living in these two major cities are expected to increase from 5.8 million (2014) to 9.2 million (2030).

While Mandalay will be a trade centre and transport hub of growing importance in Mainland South-East Asia by geopolitical location with "One Belt One Road" (OBOR) initiative of China's great policy, Mandalay cannot seize the dominance role of Yangon for at least half-century (Kim, 2018). Furthermore, while Mandalay population was $2 \%$ of the national population and contributing to $8 \%$ of GDP, about $10 \%$ of the total population resides in Yangon and contributes about a quarter of GDP (Kim, 2018). Besides, the estimate population of Mandalay will be four million in 2040 and Yangon will be megacity with over 10 million in 2040. Therefore, if the Government cannot take serious action on a long-term urban development plan for Yangon, tremendous urban issues including housing shortage and expansion of urban slums will be inevitable.

Currently, the Yangon region government has the "Strategic Urban Development Plan for the Greater Yangon" which is compiled by Yangon City Development Committee (YCDC) with support of Japan International Cooperation Agency (JICA) in 2013/2014. It is only a conceptual plan (revised in 2016) and needed to set up detail action plans of each sector. Development visions of this plan are International Hub City, Comfortable City, Well-Managed Infrastructure and Good Governance (YCDC and JICA, 2014). The main theme of the proposed conceptual plan is balancing sub-centres and compact conurbation with a public mass transit system preferably on the already existing circular railroad. Three alternative structures were proposed as (1) Sub-Centre System, (2) Sub-Centre System with Green Isles and (3) Super CBD-Single Core System and the government has tentatively decided to pursue Concept 2 . The conceptual plan is as presented in Figure 1. 


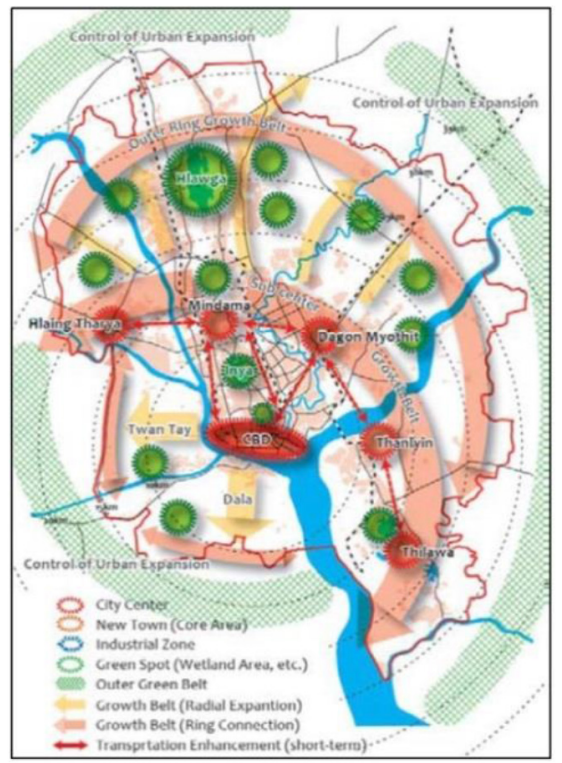

Note: Coloured version of this figure is available in the online edition of Journal of Construction in Developing Countries.

Figure 1. Sub-Centre System with Green Isles (Greater Yangon-2040) Source: DUHD and UN-Habitat (2017)

\section{Overview of Urban Housing in Myanmar}

Since 2011 , Myanmar has undergone a dramatic transition period from military ruling to the elected government and this change has surprised the global community (Jones, 2014). Additionally, economic patterns, policies and practices were transformed to a positive trend with international collaboration (Government of Myanmar, 2013). Particularly in the housing industry, where the evolution of housing policies and practices have changed remarkably over time as a consequence of political changes over four eras (Devi, 2014).

Housing supply by the DUHD as the focal department for housing sector can be shown in Table 2. Among the four political eras, only the first government regime (Parliament Democracy System, 1948-1962) had a specific National Housing Policy (NHP) under the "Pyidawtha Plan" (Public Housing Approach) with growing nationalism similar to other emerging independent countries after World War II. Under the Socialist Regime (1962-1988), there was no particular NHP because the government did not promote homeownership and they wiped out the private sector role in the economy, following socialist ideology (von der Mehden, 1963). Similarly, the housing sector under the military rulers (1988-2011) had no particular NHP and practices were ad-hoc without any long-term strategy or policy (they had applied many site and services schemes as self-help approach). Therefore, housing delivery through government schemes contributed only $1 \%$ to the housing stock. 
Table 2. Housing Provision by DUHD since Independence

\begin{tabular}{|c|c|c|c|c|c|c|c|}
\hline \multirow[b]{2}{*}{ No. } & \multirow[b]{2}{*}{ Period } & \multicolumn{2}{|c|}{ Rent } & \multicolumn{3}{|c|}{ Sold } & \multirow{2}{*}{$\begin{array}{c}\text { Total } \\
\text { Dwellings }\end{array}$} \\
\hline & & $\begin{array}{l}\text { Public } \\
\text { Rental }\end{array}$ & $\begin{array}{c}\text { Staff } \\
\text { Rental }\end{array}$ & $\begin{array}{l}\text { Low } \\
\text { Cost }\end{array}$ & $\begin{array}{l}\text { Middle } \\
\text { Cost }\end{array}$ & $\begin{array}{l}\text { High } \\
\text { Cost }\end{array}$ & \\
\hline 1 & $\begin{array}{l}\text { Parliament } \\
\text { Democracy } \\
\text { (1948-1962) }\end{array}$ & 6,601 & - & - & - & - & 6,601 \\
\hline 2 & $\begin{array}{l}\text { Socialist } \\
\text { Regime } \\
\text { (1962-1988) }\end{array}$ & 3,393 & 7,637 & - & - & - & 11,030 \\
\hline 3 & $\begin{array}{l}\text { Military Rule } \\
\text { (1988-2011) }\end{array}$ & - & 73 & 3,448 & 45,655 & 2,473 & 51,649 \\
\hline 4 & $\begin{array}{l}\text { Democratic } \\
\text { Government } \\
\text { (USDP) } \\
\text { (2011-2016) }\end{array}$ & 5,156 & 4,426 & 40,498 & 13,965 & 10,411 & 65,416 \\
\hline Total & & 15,150 & 12,136 & 34,906 & 59,620 & 12,884 & 134,696 \\
\hline
\end{tabular}

Source: DUHD (2016)

Under a long-isolated period over five decades (1962-2011), urban housing in Myanmar has not matured due to the underdeveloped nation with an agrarianbased economy, low population density combined with a huge land area, a greater ratio of rural to urban population (70:30), an abundance of natural building materials for informal housing and incapacity of the private house-builders' role (DUHD, 2012). According to the 2014 census, only $11.28 \%$ of the housing stock is formal housing, while the rest comprises of informal and temporary housing, such as huts. Even in an urban area, only $25 \%$ of housing is formal housing, $51.4 \%$ informal and $23.6 \%$ comprising huts (Department of Population, 2015).

Like other developing countries, noticeable informal housing supply can be seen in Yangon and it has alternatively provided into the gap of formal housing shortage of Yangon. Among dominated three types of informal housing supply, squatter formation and expansion are the most prominent types as of now. Yangon regional government has recognised the current squatter expansion and about 475,000 registered squatter populations (155,594 households) have been residing at the government land in 2017 (Yangon Regional Government, 2017). Another two types, i.e. informal sub-division and informal cell rental have gradually entered the informal housing market for targeted demand both MIG and urban poor.

\section{RESEARCH METHODOLOGY}

A mixed research design approach is mainly applied in this study, utilising both primary and secondary sources of data collecting, with qualitative and quantitative techniques for data analysis. The overall process of the study can be summarised as follows. First exploring dominant conditions of the housing sector is studied by qualitative approach through a combination of secondary sources as literature reviews and documents and primary sources from Klls. Overall, Yangon housing 
market is analysed with a quantitative approach through secondary data from documents and primary data including semi-structured interviews with concerned officials. Two questionnaire surveys on both demand and supply-sides are employed and analysed by Likert-type scale to identify the key constraints for private housebuilders' role on the MIG's market segment.

\section{Definition of the MIG in Yangon}

There is no standard definition or universal standardisation for the middle class because of the variations in the economic status of nations (Tarkhnishvili and Tarkhnishvili, 2013). In Myanmar, the relevant ministries could not define the official income categorisation for the MIG and no reliable survey could be found relating to income classification due to political agendas. In this study, MIG was defined on household income between USD320 (400,000 Myanmar Kyats) and USD800 (1,000,000 Myanmar Kyats) per month, as also detailed in Table 3.

Table 3. Comparison of Incomes among MIG Classification (Myanmar Kyats)

\begin{tabular}{|c|c|c|c|c|c|c|c|}
\hline No. & Definition & $\begin{array}{c}\text { Asian } \\
\text { Development } \\
\text { Bank (ADB) } \\
\text { Method }\end{array}$ & $\begin{array}{l}\text { Birdsall } \\
\text { Method }\end{array}$ & $\begin{array}{l}\text { Government } \\
\text { Employee }\end{array}$ & $\begin{array}{l}\text { Private } \\
\text { Employee }\end{array}$ & $\begin{array}{l}\text { Department } \\
\text { of Internal } \\
\text { Revenue }\end{array}$ & Remarks \\
\hline 1 & $\begin{array}{l}\text { Upper } \\
\text { middle- } \\
\text { income }\end{array}$ & $\begin{array}{l}1,650,000- \\
3,300,000\end{array}$ & & & & \multirow[t]{3}{*}{$\begin{array}{l}\text { Above } \\
400,000\end{array}$} & \multirow{3}{*}{$\begin{array}{l}\text { Converted } \\
\text { on USD } \\
\text { equivalent } \\
\text { to } 1250 \\
\text { Myanmar } \\
\text { Kyats }\end{array}$} \\
\hline 2 & $\begin{array}{l}\text { Mid } \\
\text { middle- } \\
\text { income }\end{array}$ & $\begin{array}{l}660,000- \\
1,650,000\end{array}$ & 552,000 & 300,000 & 700,000 & & \\
\hline 3 & $\begin{array}{l}\text { Lower } \\
\text { middle- } \\
\text { income }\end{array}$ & $\begin{array}{c}330,000- \\
660,000\end{array}$ & 331,000 & 180,000 & 400,000 & & \\
\hline
\end{tabular}

Source: Modified from ADB (2010)

\section{Study Area}

Yangon as the research area is situated on the part of Irrawaddy Delta forming the main arterial river for Myanmar civilisations (Kyaing, 2014). Currently, Yangon city has a total area of $792.68 \mathrm{~km}$ and an urban population of over five million, which makes up $10 \%$ of the total population and one-third of the urban population in Myanmar. A map of the Yangon study area can be seen in Figure 2. According to the 2014 census only 389,911 (24.25\%) dwelling units in Yangon were classified as standard housing with the remainder classified as substandard and temporary shelters. In terms of tenure status (2014), 485,474 units (30.6\%) were rental housing (including public, private and employer's rental) in Yangon (Department of Population, 2015). Total households in private rental housing amounted to 387,853 in 45 townships in greater Yangon. Only 33 townships are situated in the territory of the YCDC. Among the 33 townships, 19 townships can be stratified by urban ring pattern of the monocentric model. According to the registration of YCDC, about 800 contractors are registered and activate as License Contractors (LC) for the Yangon municipality area, comprising mostly of house-builders. 


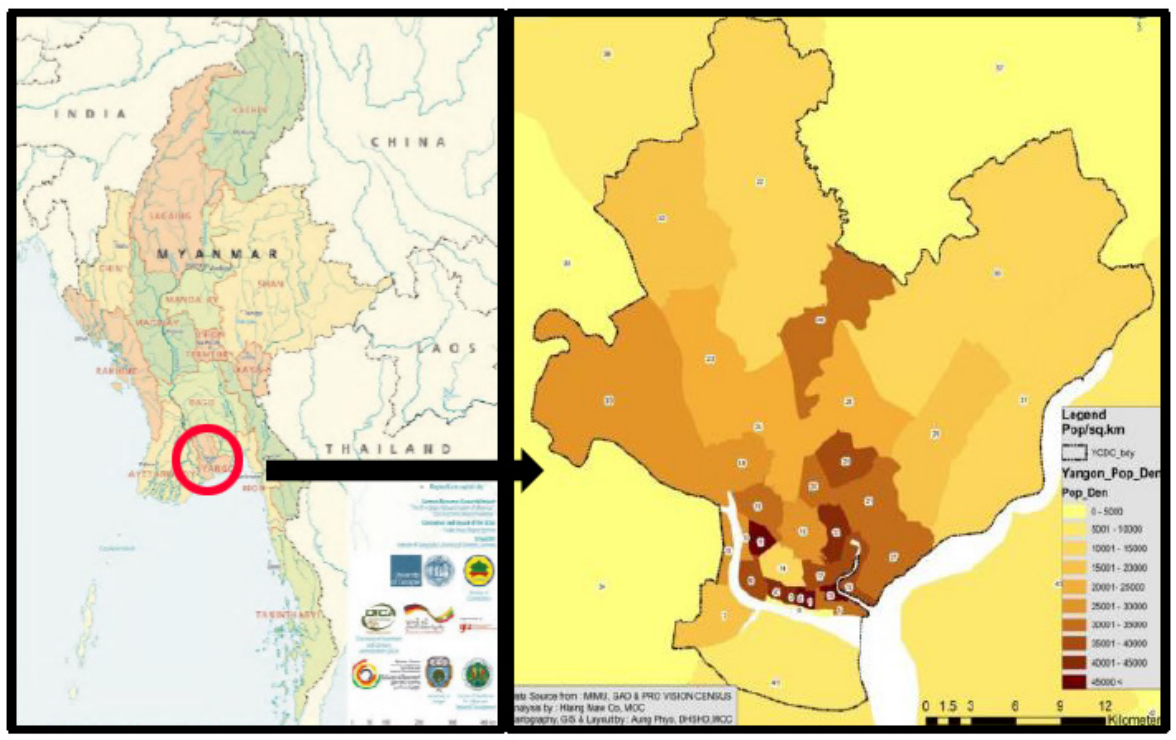

Note: Coloured version of this figure is available in the online edition of Journal of Construction in Developing Countries.

Figure 2. Map of Yangon with Population Density by Townships

Source: Kraas, Spohner and Myint (2017)

\section{Data Collection}

The collection of data can be divided into secondary as literature reviews and documents from concerned organisations and primary from semi-structured interviews, Klls, focus group discussions (FGDs) and two questionnaire surveys. Data for dominant conditions of the housing market and the current demand and supply situation are examined through the methods of historical reviews, literature reviews and collection on secondary data from related organisations mainly Department of Population, DUHD and YCDC. Data sources come from literature, secondary data, reports, expert groups and concerned officials from various departments.

Research data on MIG's preference for buying a house and key constraints of private house-builders are mainly observed on primary data. Semi-structure interviews with private house-builders, KIls with expert groups and FGDs, pilot tests for the preparation of survey questionnaires and result from two surveys for demand and supply-sides were also conducted. Among 11 interviewees whom were part of the KIls, nine of them experienced senior officials from DUHD and YCDC and two are urban economists from the university. Major topics of Klls are previous housing policies, strategies and practices, pros and cons, success and failure of the housing market, private sector participation in the housing market and condition of the interrelationship between government and private sector roles in housing.

Respondents from the demand-side are selected from current MIG tenants. The method of sampling is based on a stratified two-stage cluster sampling method for covering $10 \%$ of the total households comprising 165,571 households in the 
19 townships. As a first stage, every three wards (the smallest administrative boundary unit as part of the township) are selected by random sampling with probability proportionate to size as the 60 wards from 19 townships. As a second stage, 10 eligible rental households in each ward are selected as respondents by random selection with right-hand rule from these wards totalling 600 respondents. Survey questionnaires for the demand-side can be mainly divided into three parts as socio-economic conditions, current housing conditions and preference on buying a house by a MIG. As a pilot test, two wards (20 respondents) were collected and the demand questionnaire was revised from the response of the pilot test.

Respondents for the supply-side comprise 80 house-builders as a $10 \%$ sample of the registered contractors in Yangon with the random sampling method. Survey questionnaires for the supply-side can be divided into three parts, as the general practice of private house-builders, targeted MIG market and key constraints for private house-builders. Before collecting the survey questionnaire, the FGD was conducted with six selected house-builders for defining 25 constraints for promoting targeted market segment. In this research, the 80 respondents can be divided into 27 large-scale house-builders (34\%), 49 medium-scale house-builders (61\%) and four small-scale house-builders (5\%) (Central Statistical Organization [CSO], 2016).

\section{Data analysis}

Data Analysis is a mixed-method with quantitative and qualitative data approaches from primary and secondary resources. Trend analysis is applied to the current housing market of Yangon. Likewise, narrative analysis through KII and FGD interviews was transcribed on detailing of private house-builders' role on MIG segment. Statistical Package for the Social Sciences (SPSS) is used as the main statistical analysis of two questionnaires. The key constraints of private housebuilder' role are defined through the Likert scale with SPSS.

\section{DOMINANT CONDITIONS FOR HINDERING ON URBAN HOUSING MARKET IN YANGON}

Based on Klls and observation on secondary data, dominant conditions can be found to hinder housing market development. During the KII with professionals in the related housing sector and FGD with senior developers, they pointed out some conditions which are to be overcome for expansion of formal housing delivery. These include geographical condition, geological condition, urban transport condition, housing finance and current legal practices.

\section{Geographical Condition}

The British constructed Yangon as a port in 1852 and it has gradually grown and expanded as the capital of Myanmar until 2005 (Kyaing, 2014). It is situated at the convergence point of two rivers, which form to limit urban expansion to only about 90 degrees or quadrant of the mono-centric model. Therefore, the successive governments could gradually extend with incidental six major serial expansions within a South-North axis until the 1980s (Morley, 2013). In the 1980s, DUHD had started to expand six new satellite towns and tried to implement a new paradigm of 
East-West expansion from the elongated shape of the city towards a more rounded concentric shape (DUHD, 1988).

\section{Geological Condition}

Geological conditions similarly bound the urban pattern of Yangon into an elongated shape along the South-North axis, which formed the prevalent pattern before the 1980s. Notable geological conditions which influence urban housing development in Yangon comprise the active fault zone called the "Sagaing Fault Zone", sediment composition, groundwater resources or condition of aquifers and temporary flooding (Somsa-Ard and Pailoplee, 2013). Yangon is subjected to earthquakes from the Sagaing Fault and small and medium scale house-builders were not favourable to construct high-rise buildings due to the restricted building standards. The centrally built environment of Yangon consists of the Miocene age consolidated sediments, flanked by the quaternary age unconsolidated sediments which cause substantial constraints for high-rise building foundations. Similarly, groundwater resources can be classified into four potential zones for water supply for domestic and industrial usages by the formation of the underlying geology of Yangon (Khaing, 2011). Therefore, private housing builders are normally only interested in the inner areas as favourable habitat areas given the geological conditions of the city.

\section{Urban Transport Condition}

Similarly, urban transport development has followed geographical and geological conditions and its infrastructure (including road and rail networks) has been generally stronger along the North-South axis (JICA, 2014). Currently, bus transport is the major city transport in Yangon. It has a low quality of service provision beset with a number of problems such as poor/old vehicles, inadequate bus network and unsatisfactory provision of service information. Similarly, while a rail network was constructed during the British colonial era, the system is not reliable for daily transport use due to many reasons. Moreover, bus and rail network coverage are poor and there is no smooth interconnection between bus stops and rail stations (JICA, 2014). Similar to the South-North patterns of geological conditions, the urban extension trend and transport backbone, which dominate the urban housing sector for North-South axis extension, is also presented in Figure 3. 


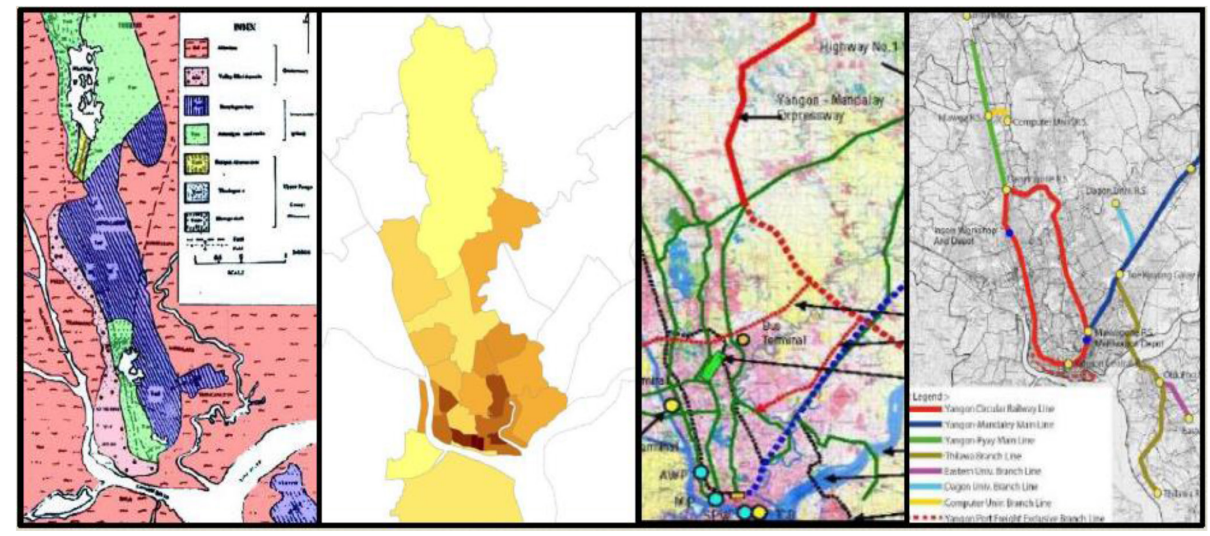

Note: Coloured version of this figure is available in the online edition of Journal of Construction in Developing Countries.

Figure 3. Comparison of Geological Conditions, Urban Extension Trend (1908s) and Urban Transport Backbones (Road and Railway) in Yangon

Source: YCDC (2016) and JICA (2014)

\section{Housing Finance Condition}

Housing finance commonly plays an important role in housing, which was only introduced to Myanmar after 2011. Housing finance mechanisms have been significantly underdeveloped due to the immaturity of the Myanmar financial market. Myanmar's financial sector is the least developed among the Association of Southeast Asian Nations or ASEAN members and it cannot adequately fulfil its role as a financial intermediary (Deutsche Gesellschaft für Internationale Zusammenarbeit [GIZ] GmbH, 2013). DUHD has tried to solve the housing finance issues since 2011 and established the Construction, Housing and Infrastructure Development (CHID) Bank in 2014. CHID Bank has introduced project loans for the supply-side and mortgage loans for the demand-side, especially low-cost housing for MIG and LIG (CHID Bank, 2015). The available resources for CHID Bank are limited for various reasons, especially the initial stages of growth, including in substantial paid-up capital, mismatch of capital mobilisation as short-term deposits and long-term loans and lack of government backing.

\section{Condition of Legal Practices}

Similarly, the legal title for housing is also an important aspect of the housing economy throughout the world (UN-Habitat, 2002). The 2017 Index of Economic Freedom, published by the Heritage Foundation and the Wall Street Journal, gave Myanmar a lowly 20 out of 100 points for property rights, in the worst category. The legal system of Myanmar is complex and outdated because of its unique character of a combination of the customary law, codified English common law and recent Myanmar legislation (Mya, 2012). Property rights are not well established and the land is forcibly taken from people and business if needed for government projects. Moreover, the lack of legitimacy for apartment ownership and problematic eviction 
from the private premise is the main legal constraints for the development of urban housing.

\section{HOUSING DEMAND IN YANGON}

Despite the low-urbanisation rate, a hint of rapid urbanisation since the early 21 st century has been seen in major cities especially Yangon. As the business capital, the urbanisation rate of Yangon is faster than other regions and states, with $70.1 \%$ of the total regional population living in urban areas. The 5.16 million urban residents settled in Yangon and the city is roughly four times bigger than the size of the second-largest city, Mandalay (Department of Population, 2015).

\section{Overall Housing Demand in Yangon}

Historical data shows that urban population growth of Yangon has been the highest and gradually grown from 2.02 million in 1973 to 2.51 million in 1983 and 5.16 million in 2014. One of the notable features of the ratio between Yangon and the national population is the significant increase during the last census in 2014, which can be compared as $14.3 \%$ with, $11.3 \%$ in 1973 and $11.2 \%$ in 1983 as shown in Table 4.

Table 4. Population Growth and Growth Rate of Yangon City

\begin{tabular}{lccccccccc}
\hline & \multicolumn{4}{c}{ Population (Million) } & \multicolumn{4}{c}{ Growth Rate } \\
\cline { 2 - 10 } Area & $\mathbf{1 9 7 3}$ & $\mathbf{1 9 8 3}$ & $\begin{array}{c}\mathbf{1 9 9 3} \\
\text { (Estimate) }\end{array}$ & $\begin{array}{c}\mathbf{2 0 0 5} \\
\text { (Estimate) }\end{array}$ & $\mathbf{2 0 1 4}$ & $\begin{array}{c}\mathbf{1 9 7 3 -} \\
\mathbf{1 9 8 3}\end{array}$ & $\begin{array}{c}\mathbf{1 9 8 3}- \\
\mathbf{1 9 9 3}\end{array}$ & $\begin{array}{c}\mathbf{1 9 9 3} \\
\mathbf{2 0 0 3}\end{array}$ & $\begin{array}{c}\mathbf{2 0 0 5 -} \\
\mathbf{2 0 1 4}\end{array}$ \\
\hline City & 2.02 & 2.51 & 3.09 & 4.35 & 5.16 & 2.20 & 2.10 & 2.89 & 1.92 \\
Outside city & 1.16 & 1.45 & 1.87 & 2.10 & 2.20 & 2.26 & 2.58 & 0.97 & 0.52 \\
Yangon region & 3.18 & 3.96 & 4.96 & 6.45 & 7.36 & 2.20 & 2.26 & 2.21 & 1.48 \\
Myanmar & 28.08 & 35.30 & 43.11 & 54.68 & 51.48 & 2.02 & 2.02 & 2.00 & -0.67 \\
\hline
\end{tabular}

Source: Department of Population (2015)

Otherwise, population growth could be calculated, as an increase of about 90,000 per year during the period 2005 to 2014. Therefore, the demand for housing could be estimated at 20,000 new dwellings needed for the annual population growth. This estimate calculates only new household formation with mean family size (4.4 persons) and excludes the current housing stock. According to the census (2014), standard housing is only $24.25 \%$ with the remainder requiring refurbishment to building standard. Therefore, housing demand in Yangon can be predicted at roughly over 20,000 dwellings per year. Moreover, Yangon population will be rapidly grown by internal migration for many reasons (Internal Displacement Monitoring Centre [IDMC], 2008). Yangon is usually the final destination for internal migration and $42.3 \%$ of the Yangon population has migrated from all other regions. This population growth is likely to push a high demand for housing in future with the projected growth, which can be seen in Table 5. 
Table 5. Projected Population of Yangon (2021-2031)

\begin{tabular}{llccccccc}
\hline No. & $\begin{array}{l}\text { Region/ } \\
\text { Nation }\end{array}$ & $\begin{array}{c}\text { Current } \\
\text { Population } \\
\text { (Million) } \\
\text { (2014) }\end{array}$ & $\begin{array}{c}\text { Projected } \\
\text { Population } \\
\text { (Million) } \\
\text { (2021) }\end{array}$ & $\begin{array}{c}\text { Growth } \\
\text { Rate }\end{array}$ & $\begin{array}{c}\text { Projected } \\
\text { Population } \\
\text { (Million) } \\
\text { (2026) }\end{array}$ & $\begin{array}{c}\text { Growth } \\
\text { Rate }\end{array}$ & $\begin{array}{c}\text { Projected } \\
\text { Population } \\
\text { (Million) } \\
\text { (2031) }\end{array}$ & $\begin{array}{c}\text { Growth } \\
\text { Rate }\end{array}$ \\
\hline 1 & $\begin{array}{l}\text { Yangon } \\
\text { region }\end{array}$ & 7.36 & 8.68 & $17.9 \%$ & 9.69 & $11.6 \%$ & 10.72 & $10.6 \%$ \\
2 & Myanmar & 51.49 & 55.29 & $7.3 \%$ & 57.63 & $4.2 \%$ & 59.80 & $3.7 \%$ \\
\hline
\end{tabular}

Source: Department of Population (2015)

\section{Housing Demand by MIG Segment}

Like other Asian developing countries, the emerging of the MIG can be seen in Yangon by many reasons especially transforming of economic pattern, increase of international investment, improvement of educational status, increasing of job opportunities for potential MIG. Survey questionnaire results strongly pointed out that MIG willing to be a homeowner but they are deterred from entering to formal housing market due to unaffordability.

\section{Socio-economic condition of the MIG in Yangon}

According to the demand-side survey result, 340 (58.7\%) of MIG are natives of Yangon with the rest comprising internal migrants. In terms of educational status, majority of the respondents (81\%) attained primary and secondary educations, only $18.3 \%$ are university graduate and only two respondents attained postgraduate and doctorate levels. Regarding the occupation, only $14.8 \%$ have a regular income job as permanent employees in the government and private sector that have eligibility for a housing mortgage. Majority of occupation are mainly transient labour as (43.9\%) and the rest can be categorised into skill and semi-skill labour $(36.6 \%)$ and small owned businesses as (4.7\%). The majority of respondents have only one child or two children, $37.8 \%$ and $25.2 \%$ respectively and the average family size in Yangon can be slightly smaller than the national family size ( 4.4 persons per household). Most of the households have two income earners (46.1\%). Only oneincome earner households comprise $16.6 \%$, with three-income earners comprising $23 \%$ of households. The remainder comprises four and above earners. Monthly household income can be categorised into three groups. They are: (1) mainly USD320 to USD480 (76.5\%), (2) USD480 to USD640 (22.1\%) and (3) above USD640 (1.4\%). Most of the monthly expenditure can be categorised under USD240 (86.5\%) as the majority, USD240 to USD400 (12.6\%) and rest are above USD400.

\section{Current housing conditions of the MIG}

As a least developed country, the majority of housing types use outdated traditional construction techniques, including owner-self build housing by local carpenters and masons. Current housing types and sizes can be found in Figure 4. Most of the respondents reside in mainly wooden houses (traditional house built by local carpenters) (49.9\%), two-storey wooden houses (13.5\%) and other types are room type apartments $(0.9 \%)$, hall type apartments (narrow pattern without partition) 
(33\%) and brick noggin (a construction technique in which bricks are used to fill the vacancies in a wooden frame) (2.8\%). Therefore, the products of professional house-builders are fewer than only one-third of respondents. The majority (53.5\%) of housing sizes are suitable for typical household (four or five persons) as a floor area (600 to 1,000 sq. ft). Monthly rental fees are roughly USD100. To be exact, the fees are USD40 (23.8\%), USD40 to USD80 (42.5\%), USD80 to USD160 (29.7\%) and the remaining are over USD160 (4\%). Although they want to be homeowners, the majority of respondents are satisfied with the current location of their rental home for the convenience of access to transportation.

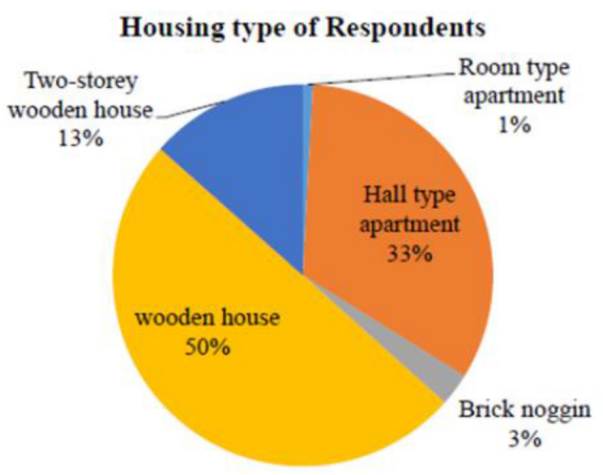

\section{Room Size of Respondents}

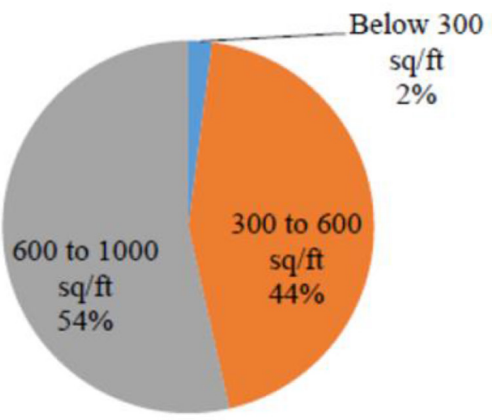

Figure 4. Current Housing Types and Sizes of Tenants for MIG in Yangon

\section{MIG's preference for buying a house}

Out of all 600 respondents, $60.9 \%$ want to buy medium size apartments between 600 to 1,000 sq. ft, $16 \%$ expect to have small size apartments between 300 to 600 sq. ft and $21 \%$ want to have detached houses. Mainly, most of the respondents would like to have apartments with two bedrooms (63.9\%), one-bedroom (21.7\%) and three bedrooms (12\%). Most respondents (96.7\%) targeted a housing price of around USD24,000 with a housing mortgage. Affordable down payments amounted to USD2,400 for the majority (95.9\%). Government housing delivery has trust from $87 \%$ of the respondents and only 47 respondents $(8.1 \%)$ want to buy products by famous private house-builders. The criterion for selecting a house is based mainly on housing price. The second reason is transportation and the third priority for selection is local services and facilities.

\section{HOUSING SUPPLY IN YANGON}

Formal housing supply can be mainly divided into two groups: housing delivery by government organisations and private house-builders. Among the government organisations, DUHD is the responsible organisation, as well as the main provider of various public housing schemes. DUHD attempted to provide better living conditions to all citizens in every era but public opinion has been negative to their efforts. 
DUHD can only fulfil lower than $10 \%$ of current housing stock in Yangon and the rest of them were provided by private house-builders.

\section{Formal Housing Supply by DUHD}

Housing provision by DUHD cannot meet the housing demand in Yangon, especially under the socialist and military regimes, as mentioned previously. After the 2011 election, DUHD had boosted its capacity to promote the role of government in the housing sector. Housing provision by DUHD under the first elected government (USDP) term can be stated as in Table 6.

Table 6. Housing Provision by DUHD in Yangon (2011 to 2016)

\begin{tabular}{ccccccc}
\hline No. & Budget Year & $\begin{array}{c}\text { Number of } \\
\text { Projects }\end{array}$ & $\begin{array}{c}\text { Low-Cost } \\
\text { Housing }\end{array}$ & $\begin{array}{c}\text { Mid-Cost } \\
\text { Housing }\end{array}$ & $\begin{array}{c}\text { High-Cost } \\
\text { Housing }\end{array}$ & Total Dwellings \\
\hline 1 & $2011 / 2012$ & 12 & - & 969 & 201 & 1,170 \\
2 & $2012 / 2013$ & 9 & 10,800 & 1,032 & 6,103 & 17,935 \\
3 & $2013 / 2014$ & 12 & 2,332 & 2,588 & 43 & 4,963 \\
4 & $2014 / 2015$ & 7 & 6,202 & 1,359 & - & 7,561 \\
5 & $2015 / 2016$ & 30 & 11,160 & 5,589 & 4,382 & 21,131 \\
\hline & Total & 70 & 30,494 & 11,537 & 10,729 & 52,760 \\
\hline
\end{tabular}

Source: DUHD (2016)

Housing production by DUHD under the democratic government (USDP) was facing a noticeable issue of site selection. Most of the housing projects are situated in periurban areas because the DUHD has only reserved land in new satellite towns. These locations are far from the downtown or workplace of the middle class and the public estates further out will not attract the MIG, due to transportation problems and inaccessibility to socio-economic services and amenities.

In April 2016, anti-military Democratic Party (National League for Democracy [NLD]) won an election and succeeded to national power, the NLD government cannot implement particular activities related housing sector until the end of 2018. The president addressed in his Myanmar New Year 2018 speech that housing is a vital need for citizens and recognition on the housing shortage. Similarly, the housing agenda has been stated in Myanmar Sustainable Development Plan (MSDP) (2018 to 2030) declared in August 2018 (Government of Myanmar, 2018). The ultimate development goal is "A Peaceful, Prosperous and Democratic Myanmar" and the government set up in detail as "3 Pillars, 5 Goals, 28 Strategies and 251 Action Plans". Housing agenda including slum issues are addressed in an Action Plan. However, the NLD government cannot increase public housing production and that can be compared to public housing delivery under NLD government in Table 7. 
Table 7. Housing Provision by DUHD in Yangon (2016 to 2018)

\begin{tabular}{ccccccc}
\hline No. & Budget Year & $\begin{array}{c}\text { Number of } \\
\text { Projects }\end{array}$ & $\begin{array}{c}\text { Low-Cost } \\
\text { Housing }\end{array}$ & $\begin{array}{c}\text { Mid-Cost } \\
\text { Housing }\end{array}$ & $\begin{array}{c}\text { High-Cost } \\
\text { Housing }\end{array}$ & Total Dwellings \\
\hline 1 & $2016 / 2017$ & 3 & 2,118 & - & - & 2,118 \\
2 & $2017 / 2018$ & 8 & 3,664 & 318 & - & 3,982 \\
\hline & Total & 11 & 5,782 & 318 & & 6,100 \\
\hline
\end{tabular}

Source: DUHD (2018)

\section{Housing Supply by Private House-Builders}

While the private house-builder's role is a key provider for formal housing supply in Yangon and provided $90 \%$ of housing stock, they cannot fulfil the annual demand efficiently. Theoretically, private house-builders are always eager to extend their business activity for profit maximisation. In reality, there are many factors, which can hinder raising the level of production and provision of housing with high risk for private house-builders (Shaqra'a, Badarulzaman and Roosli, 2015). According to both surveys, although MIG's preference is feasible and workable for private housebuilders, they could not enter this market segment in the current situation due to many constraints.

\section{Formal housing supply by private house-builders}

Although business practices of private house-builders are not mature within the corporate culture and professional management, this role has been more prominent in the housing sector after the collapse of Socialism in 1988 (Ministry of Planning and Finance, 2016). Especially, capacities of some house-builders have been stronger with technical transfer and capital mobilisation during the current decade in Yangon. Annual production of formal housing provision cannot be counted in detail because building permission by YCDC is officially applied for a five-year term. According to estimates, the private sector annually produced about 2,000 to 9,000 dwellings as standard housing supply since 1992, averaging about 7,000 units over the period, which was around one-third of the housing need in Yangon. Annual finished housing units can roughly be counted through the issuing of Building Completion Certificates (BCCs). Issuing for BCCs and permission for building can be counted annually in Figure 5 and Table 8. 


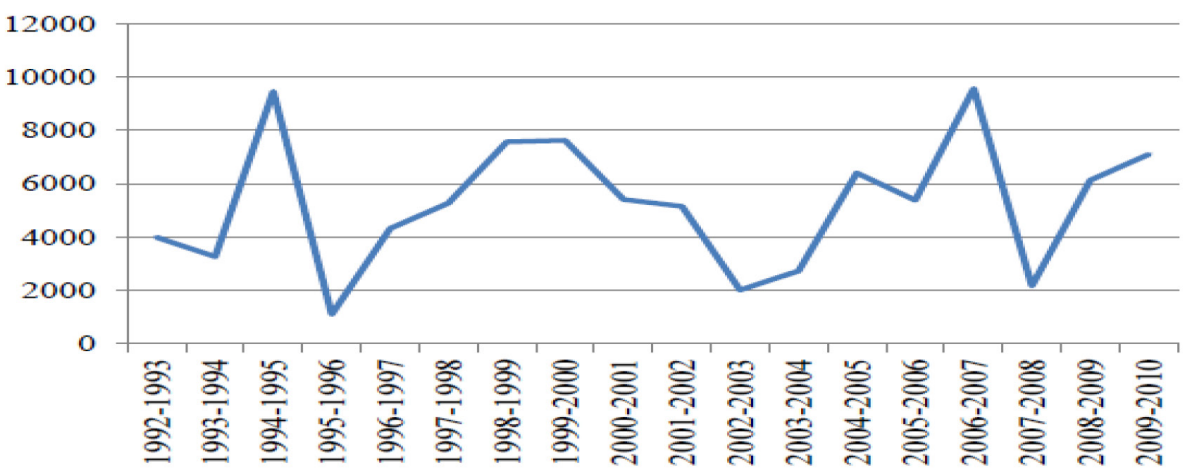

Figure 5. Annual BCCs Issued by YCDC in Yangon (1992 to 2010) Source: YCDC (2010)

Table 8. Building Permission by YCDC (2011 to 2016)

\begin{tabular}{lcccc}
\hline No. & Year & High-Rise Building & Low-Rise Building & Total \\
\hline 1 & 2011 & 479 & 1,504 & 1,983 \\
2 & 2012 & 293 & 2,026 & 2,319 \\
3 & 2013 & 748 & 3,548 & 4,296 \\
4 & 2014 & 3,070 & 4,030 & 7,100 \\
5 & 2015 & 3,384 & 3,240 & 6,624 \\
6 & 2016 & 1,381 & 2,322 & 3,703 \\
7 & 2017 & 753 & 2,803 & 3,556 \\
\hline
\end{tabular}

Source: YCDC (2017)

\section{Private house-builders' role in housing market}

In Yangon, the majority of house-builders normally act as both land developer and contractor on all construction projects for buildings and infrastructures. Most of the companies are family businesses and a few large-scale companies have been trying to organise professional business within an international corporate culture. Most of the large-scale companies normally outsource business planning and design, hiring machinery on a project by project basis, even though they have a small in house engineer group. Therefore, they try to find good local and foreign partners for constructing sizable projects. The main challenge for all companies is capital mobilisation for large-scale projects, due to lack of equity financing and high-interest rates.

As medium scale companies, they are generally subcontractors of large-scale company projects and they have tried to start small residential and commercial real estate projects. Most of the small-scale contractors are almost sole ownership and they have no management and technical support. They normally construct singledetached houses (organic housing), walk-up apartments and small infrastructure projects, especially through subcontracting from construction companies. 
Annual housing production by house-builder companies can be presented in Table 8. Among the 80 surveyed respondents as house-builders, only one company has the International Organization for Standardization (ISO) certification. For ownership, the majority is in sole ownership representing 56 respondents (70\%), with 23 companies (29\%) in partnerships and only one company is a public company. Construction technologies and practices are outdated with craft production. Therefore, the majority of house-builders can produce fewer than a hundred dwellings per year and only five companies (6\%) can produce 300 to 500 dwellings annually.

Table 9. Annual Housing Production Rate by Private House-Builders

\begin{tabular}{lccc}
\hline No. & Annual Production (Dwelling) & Respondents & Percentages \\
\hline 1 & 300 to 500 units & 5 & $6 \%$ \\
2 & 120 to 300 units & 9 & $11 \%$ \\
3 & 20 to 120 units & 40 & $50 \%$ \\
4 & Under 20 units & 26 & $33 \%$ \\
& Total & 80 & $100 \%$ \\
\hline
\end{tabular}

\section{Substandard housing supply by private house-builders}

Another notable issue is substandard housing produced by small house-builders. Small house-builders do not want to obey regulations and bylaws because of bureaucratic and transaction costs. They always construct two units per floor six storey walk-up apartments without official permission. Although the quality of substandard buildings is non-compliant with building codes, they can attract MIG and LIG because of affordable prices. For example, data from YCDC pointed to 1,638 substandard buildings constructed during 2015 in many townships, especially in old and new suburban areas (YCDC, 2016).

\section{ANALYSIS OF HOUSING MARKET AND ROLES OF PRIVATE HOUSE-BUILDERS}

Yangon housing market is a poorly functioning market with fragile key players as government, financial institutions and private house-builders. The housing market of Yangon is facing tremendous shortage with the insufficient supply by both public and private sector. If governments do not take serious action on the urban housing sector, the condition will be gradually worse than it was under military rulers. Moreover, increasing informal housing can harm housing resilience from disasters and climate change which is a critical global agenda of the 21 st century.

\section{Analysis of Housing Market in Yangon}

As current housing stock, only one-fourth of housing is standard housing and rest of them are substandard and temporary shelters. Notoriously, round about a quarter of houses is hut $(23.6 \%)$ which is inadequate for living. While the majority of successive 
governments did not prioritise housing as a national agenda except parliament democracy government (1948 to 1962), several main causes can deter the housing sector development. These are the underdeveloped nation with an agrarian-based economy, low population density combined with a huge land area, a greater ratio of rural to urban population (70:30), an abundance of natural building materials for informal housing and incapacity of the private house-builders' role.

Moreover, housing demand can increase rapidly by pushing the urbanisation rate of Yangon. Annual housing demand is round about 20,000 which do not include the need for improvement of current housing stock. Yangon is predicted to be a megacity during two or three decades with rapid internal migration due to many reasons. Mainly, change of economic pattern (agro-based to industrial and services based economy), decline and instability of agriculture sector with climate change and dreadful natural and man-made disaster which have been increasing population growth and fueling occurrence of over housing demand like as other developing countries (Chai, Yusof and Habil, 2015).

On the other hand, current formal housing supply (mainly by private housebuilders) can fulfil only one-third of annual demand (about 7,000 to 9,000). Moreover, the trend of formal housing supply has not been rising upward and private housebuilders cannot expand their production especially affordable housing for MIG due to many constraints. Therefore, increasing informal housing supply (replacement of formal supply) can be seen in Yangon's housing market as inevitable phenomena of other developing countries. Currently, only registered squatter on government land can be counted to nearly half-million (10\% of the total population) which is at least double the amount of previous two major squatter formations during 20th century in Yangon.

Besides, according to the results from KII and literature review, it is found out that some conditions can be dominant on housing sector development. Among them, five natural and structural conditions mainly hinder to expanding private house-builder's roles on MIG segment. These include geographical and geological conditions as natural conditions and public transport, housing finance and legal practices related to housing as structural conditions.

\section{Private House-Builders' Role on MIG Market Segment}

While emerging of the MIG can be seen in Yangon, their purchasing power for house is not too increasing due to overall economic development. Majority of MIG have irregular income jobs for ineligibility of housing mortgage and average modes of monthly income are between USD320 to USD480. Although they currently reside as tenant status, they want to be a homeowner for standard houses especially apartment ownership. They preferred to buy a medium size of room type apartment and they can afford about 30 million kyats or USD24,000 with a housing mortgage. They are willing to pay (WTP) for a house by MIG as 6.25 (house-price-to-annual income ratio) which is higher than a rule of thumb by UN-Habitat as 3.5 and 5.8 in highly industrialised countries (Cruz, 2008). Besides, most of MIG want to rely on public housing delivery and they considered that private house-builders cannot fulfil their expectation.

On the other hand, although private house-builders are key players for the housing market, their business practice is not too mature because of the lengthy isolated period under socialism and military regimes. Most of the private housebuilders are family business types and a few large-scale companies have 
been trying on transforming professional business with corporate governance. In current, large and medium private house-builders have mainly focused on highcost and luxury apartment for high-income group and small private house-builders consider producing MIG but substandard houses. All of the private house-builders believe that MIG housing market is a potential market segment but they cannot provide the MIG preferred houses (price bracketing 30 to 50 million kyats equivalent USD24,000 to USD40,000) due to many constraints.

\section{Key Constraints of the Private House-Builders Role on MIG Segment}

It is a universal truth that private house-builders always extend housing delivery by profit-driven, they could not entirely fulfil housing demand for MIG segment due to many constraints. During the KII and FGD sessions, professional and house-builders has mentioned many constraints which hinder to provide housing for MIG and all stakeholders should try to overcome for housing sector development. There are 25 constraints on formal housing supply for MIG which is the outcome of the interviews as in Table 10.

Table 10. Constraints for Private House-Builders for MIG Identified by Key Informants

\begin{tabular}{|c|c|c|c|}
\hline Code & Constraint & Code & Constraint \\
\hline $\mathrm{COl}$ & Low purchasing power & $\mathrm{C} 14$ & High construction costs \\
\hline $\mathrm{CO} 2$ & $\begin{array}{l}\text { Transitory nature of the } \\
\text { economy }\end{array}$ & $\mathrm{C} 15$ & High investment risks \\
\hline $\mathrm{CO3}$ & Unstable economy & $\mathrm{C} 16$ & High transaction costs \\
\hline $\mathrm{CO4}$ & $\begin{array}{l}\text { High demand for high-income } \\
\text { housing }\end{array}$ & $\mathrm{C} 17$ & Frequent booms and busts \\
\hline C05 & Low government commitment & $\mathrm{C} 18$ & Lack of professional management \\
\hline $\mathrm{CO6}$ & High bureaucratic cost & $\mathrm{C} 19$ & Fear of damage to reputation \\
\hline C07 & Shortage of infrastructure & $\mathrm{C} 20$ & Outdated legal system \\
\hline C08 & Costly and unreliable transport & $\mathrm{C} 21$ & Weak business sector \\
\hline C09 & Access to public information & $\mathrm{C} 22$ & The strong informal housing sector \\
\hline $\mathrm{C} 10$ & Low-profit margin & $\mathrm{C} 23$ & An unregulated pre-sale market \\
\hline $\mathrm{Cl1}$ & $\begin{array}{l}\text { Underdeveloped real estate } \\
\text { companies }\end{array}$ & $\mathrm{C} 24$ & Unattractive peri-urban areas \\
\hline $\mathrm{C} 12$ & High land prices & $\mathrm{C} 25$ & Lack of clear building regulations \\
\hline $\mathrm{C} 13$ & $\begin{array}{l}\text { Underdeveloped financial } \\
\text { sector }\end{array}$ & & \\
\hline
\end{tabular}

These 25 constraints were presented to the 80 respondents in the sample of privatesector developers. Using a Likert scale, respondents were asked to rate their agreement or disagreement with the constraints to identify the important constraint from among the listed 25 constraints (a five-point Likert scale as 1 = Totally Disagree; 
2 = Disagree; 3 = Neutral; 4 = Agree; 5 = Totally Disagree) for formal housing delivery to the MIG.

Among the listed 25 constraints for private house-builders to provide formal housing supply for MIG, seven constraints are most important as shown in Figure 6. They are "Underdeveloped financial sector" (C13), "Weak business sector" (C21), "High bureaucratic cost" (C06), "High land prices" (C12), "Shortage of infrastructure" (C07), "Low government commitment" (C05) and "Access to public information" (C09).

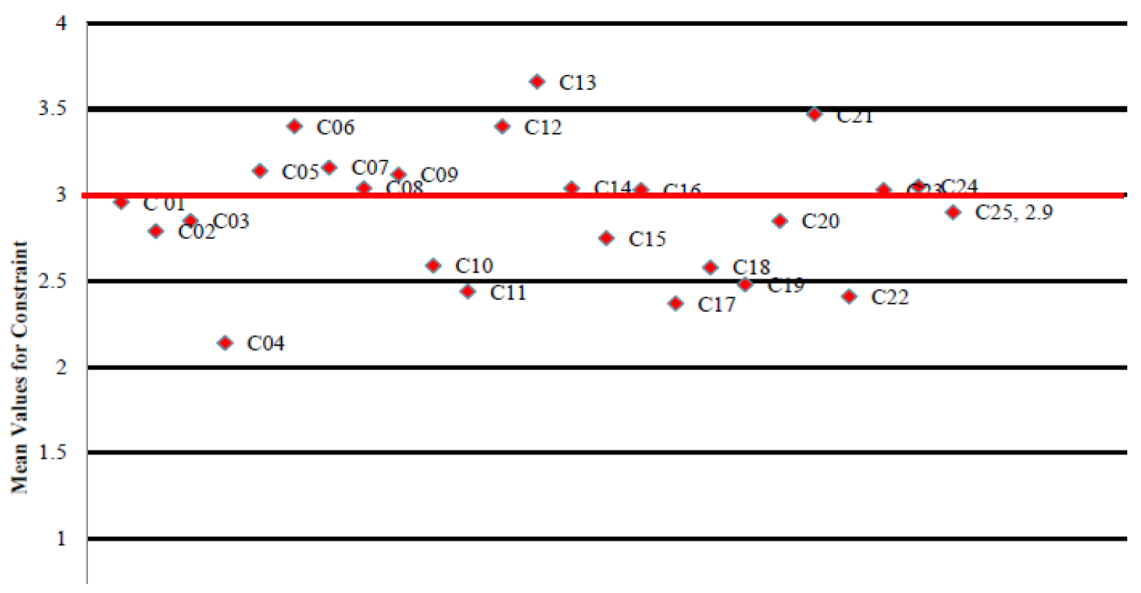

Figure 6. Key Constraints for Private House-Builders' Role by Likert Scale

Upon analysis on these key constraints, four constraints as "Underdeveloped financial sector", "Weak business sector", "High bureaucratic cost" and "Low government commitment" which are common negative characters of a transition period from Socialism to Democracy. "High land prices" and "Shortage of infrastructure" are the same phenomena of agglomerated cities in the third world and key constraint as access to public information is related to underdeveloped nation status. Besides, it can be found that these are related to three focus areas of the World Bank's enabling approach as demand-side, supply-side and institutional framework except "Access to public information" (C09). Therefore, constraints of MIG segment are more similar to Nigeria's experiences but different from Iran (focus on supply-side and institution framework) and South Africa's applied strategies (focus on the demand-side).

Although, with enabling approach as current global housing policy paradigm, it cannot provide detail policy road map for policymakers and each government need policy reform which is in line with salient issues and current condition of the respective country. Iran government concentrated on promoting the role of government through two main areas such as supply-side and institution framework and South Africa had focused only on demand-side especially financial subsidies and housing finance mechanism (Keivani, Mattingly and Majedi, 2005; Jones and Datta, 2000). Nigeria had applied a multidimensional approach on all salient issues as housing finance, access to land, residential infrastructure, institutional regulations and building materials (Ogu and Ogbuozobe, 2001). Key constraints of Yangon 
market are similar to salient Nigeria's issues except for lack of public information related housing sector (information platform as a 21 st century agenda of the third world). Moreover, private house-builders highly regard on low government commitment which should be firmly considered since they are the starting point of housing sector policy reform.

\section{CONCLUSION}

Like other developing countries, Yangon housing market has been facing the immensity of housing shortage by over demand and has been fueling by rapid internal migration. About the current housing situation, a quarter of housing stock is only standard housing and the remainder is needed to refurbish or renovate. Besides, the urban housing agenda has become more challenging, as some natural and structural conditions are dominant for shaping urban housing in Yangon. With the currently growing demand in Yangon, the private house-builders could produce only around one-third of annual demand. This housing shortage can distort market stability and formal housing supply beyond the reach of the MIG and pushing the informal housing market. It was also found that private house-builders cannot expand to the MIG market beset with seven key constraints, the most important constraints are "Underdeveloped financial sector", "Weak business sector" and "High bureaucratic cost" for private house-builders' role on MIG housing segment.

Although urban housing problems in the developing countries are similar symptom by poverty and mismanagement, solutions can be different based on conditions of respective cities. Majority of study on constraints which focused on supply-side especially price fluctuation, but this article explored constraints in the private sector under transition period in the developing country. It spotlighted the current situation as a large unmet demand for urban housing in Yangon. As the transition period of a Socialist country with a planned economy to the market economy, Myanmar government needs to facilitate the private sector since it is the main driver of the national economy. While enabling approach is recommended for implementing in developing countries such as Myanmar, the government needs to decide how these principles are to be translated into concrete policy reform and workable plan towards right direction with overcoming key constraints for private house-builders of Yangon.

Therefore, exploring dominant conditions and defining key constraints could be utilised to set applicable policies and strategies for housing sector development in Yangon. Moreover, while other constraints are neglected by private housebuilders, some constraints can be important for further dimensions such as "Low purchasing power of MIG" (C01) and "Outdated legal system" (C20). Limitations of the study include getting reliable and consistent data and lack of citing academic documents for Myanmar context. This article focuses only on the private housebuilders and further researches should be recommended on other key players and basic elements of urban housing especially roles of government and financial institutions.

\section{ACKNOWLEDGEMENT}

The authors would like to thank the members of the programme committee for their comments and suggestions. This research was also supported by the 
Department of Urban and Housing Development, Ministry of Construction, Myanmar. In addition, the authors would also like to express their gratitude to the respondents of this research.

\section{REFERENCES}

Asian Development Bank (ADB) (2010). Key Indicators for Asia and the Pacific. Manila: ADB.

Aura, A. and Davidoff, T. (2006). Supply Constraints and Housing Prices. Munich: Center for Economic Studies and Ifo Institute.

Buckley, R.M., Faulk, D. and Olajide, L. (1997). Private Sector Participation, Structural Adjustment and Nigeria's New National Housing Policy: Lessons from Foreign Experiences. Washington DC: World Bank.

Central Statistical Organization (CSO) (2016). Myanmar Business Survey 2015 Data Report. Nay Pyi Taw: UNDP and CSO.

Chai, C.S., Yusof, A.M. and Habil, H. (2015). Delay mitigation in the Malaysian housing industry: A structural equation modelling approach. Journal of Construction in Developing Countries, 20(1): 65-83.

Construction, Housing and Infrastructure Development (CHID) Bank (2015). Annual Report (2015). Yangon: CHID Bank.

Cruz, P.C.R. (2008). Transaction costs and housing affordability in Asia. International Real Estate Review, 11(1): 128-150.

Department of Population (2015). The 2014 Myanmar Population and Housing Census. Nay Pyi Taw: Ministry of Immigration and Population.

Department of Urban and Housing Development (DUHD) (2018). National Urban Policy Framework. Nay Pyi Taw: Unpublished.

(2016). Five Years Report (2011-2016). Nay Pyi Taw: DUHD.

- (2012). Policy Paper for NCDP. Nay Pyi Taw: Ministry of Construction.

—. (1988). Housing Development during (1962-1987). Yangon: DUHD.

DUHD and United Nations Human Settlements Programme (UN-Habitat) (2017). Rapid Urban Diagnostic Report. Nay Pyi Taw: Unpublished.

Deutsche Gesellschaft für Internationale Zusammenarbeit (GIZ) GmbH (2013). Myanmar's Financial Sector a Challenge Environment for Banks. Yangon: GIZ.

Devi, K.S. (2014). Myanmar under the military rule 1962-1988. International Research Journal of Social Sciences, 3(10): 46-50.

Dobermann, T. (2016). Urban Myanmar. London: International Growth Centre.

Eni, D.D. and Danson, T.P.K. (2014). Private sector participation in urban housing supply in Calabar, Nigeria. American International Journal of Contemporary Research, 4(8): 130-141.

Golubchikov, O. and Badyina, A. (2012). Sustainable Housing for Sustainable Cities: A Policy Framework for Developing Countries. Nairobi: UN-Habitat.

Government of Myanmar (2018). Myanmar Sustainable Development Plan (20182030). Nay Pyi Taw: Ministry of Planning and Finance.

— (2013). Framework for Socio Economic Reform. Nay Pyi Taw: Government of Myanmar.

Hilber, C. and Vermeulen, W. (2012). The Impact of Supply Constraints and House Price in England. London: Spatial Economics Research Centre. 
Ibem, E.O. (2010). As assessment of the role of government agencies in publicprivate partnerships in housing delivery in Nigeria. Journal of Construction in Developing Countries, 15(2): 23-48.

Internal Displacement Monitoring Centre (IDMC) (2008). Myanmar (Burma): No End Insight for Internal Displacement Crisis. Yangon: IDMC.

Ismail, S. (2013). Factors attracting the use of public private partnership in Malaysia. Journal of Construction in Developing Countries, 18(1): 95-108.

Japan International Cooperation Agency (JICA) (2014). Yangon's Urban Transportation: Traffic Demand and its Quality of Services. Yangon: JICA.

Jones, G.A. and Datta, K. (2000). Enabling markets to work? International Planning Studies, 5(3): 393-416. https://doi.org/10.1080/713672861.

Jones, L. (2014). The political economy of Myanmar's transition. Journal of Contemporary Asia, 44(1): 144-170. https://doi.org/10.1080/00472336.2013.7 64143.

Keivani, R. and Werna, E. (2001). Modes of housing provision in developing countries. Progress in Planning, 55(2): 65-118. https://doi.org/10.1016/S03059006(00)00022-2.

Keivani, R., Mattingly, M. and Majedi, H. (2005). Enabling Housing Markets or Increasing Low Income Access to Urban Land: Lessons from Iran. Washington DC: World Bank.

Khaing, K.K. (201 1). Ground water utilization and availability in Yangon City. University Research Journal, 4(5): 175-190.

Kim, Y. (2018). Mandalay, Myanmar: The remarking of a South-east Asian hub in a country at the crossroads. Cities, 72: 274-286. https://doi.org/10.1016/j. cities.2017.09.003.

Kraas, F., Spohner, R. and Myint, A.A. (2017). Socio-Economic Atlas of Myanmar. Cologne, Germany: University of Cologne.

Kyaing, K. (2014). Urban Land Use Pattern and Residential Land in Yangon. Yangon: Yangon Institute of Economics.

Leonard, J.B. (1985). City profile Rangoon. Cities, 2(1): 2-13. https://doi. org/10.1016/0264-2751(85)90057-5.

Leung, C. (2004). Macroeconomics and housing: A review of the literature. Journal of Housing Economics, 13(4): 249-267. https://doi.org/10.1016/j.jhe.2004.09.002.

Malpezzi, S. (1999). Economic analysis of housing markets in developing and transition economies. In P.C. Cheshire and E.S. Mills (eds.), Handbook of Regional and Urban Economic. Vol. 3. Amsterdam: Elsevier Science.

Ministry of National Planning and Economic Development (MNPED) (2015). National Comprehensive Development Plan. Nay Pyi Taw: MNPED.

Ministry of Planning and Finance (MoPF) (2016). Myanmar Indicative Private Sector Development Framework and Action Plan. Nay Pyi Taw: Ministry of Planning and Finance.

Morley, I. (2013). City profile Rangoon. Cities, 31: 601-604. https://doi.org/10.1016/j. cities.2012.08.005.

Mya, S. (2012). Myanmar Customary Law. Yangon: Gonhtoo Sarpay.

Ogu, V.I. and Ogbuozobe, J.E. (2001). Housing policy in Nigeria: Towards enablement of private housing development. Habitat International, 25: 473-492. https://doi.org/10.1016/S0197-3975(01)00018-2.

Paciorek, A. (2011). Supply Constraints and Housing Market Dynamics. Washington DC: Federal Reserve Board. 
Sengupta, U. (2006). Government intervention and public-private partnerships in housing delivery in Kolkata. Habitat International, 30(3): 448-461. https://doi. org/10.1016/j.habitatint.2004.12.002.

Shaqra'a, E.A.A, Badarulzaman, N. and Roosli, R. (2015). Residents' perception of the affordability of private housing schemes: Lessons from Aden, Yemen. Procedia - Social and Behavioral Sciences, 202: 389-399. https://doi. org/10.1016/j.sbspro.2015.08.243.

Shuid, S. (2015). The housing provision system in Malaysia. Habitat International, 54: 210-223. https://doi.org/10.1016/j.habitatint.2015.11.021.

Sivam, A., Evans, D., King, R. and Young, D. (2001). An approach to improved housing delivery in large cities of less developing countries. Habitat International, 25: 99-1 13. https://doi.org/10.1016/S0197-3975(00)00032-1.

Somsa-Ard, N. and Pailoplee, S. (2013). Seismic hazard analysis for Myanmar. Journal of Earthquake and Tsunami, 7(4): 14. https://doi.org/10.1142/ S1793431113500292.

Sullivan, A. (2007). Urban Economics. New York: McGraw-Hill.

Tarkhnishvili, A. and Tarkhnishvili, L. (2013). Middle class: Denifition, role and development. Global Journal of Human Social Science, 13(7): 21-31.

UN-Habitat (2002). Review of International and National Legal Instruments. Nairobi: UN-Habitat.

Urban Research and Development Institute (URDI) (2013). Interim Report. Yangon: URDI.

von der Mehden, F.R. (1963). The Burmese way to socialism. Asian Survey, 3(3): 129135. https://doi.org/10.2307/3023620.

Wang, Z. and Zhang, Q. (2014). Fundamental factors in the housing markets of China. Journal of Housing Economics, 25: 53-61. https://doi.org/10.1016/j. jhe.2014.04.001.

Witwer, M. (2007). An Untapped Resource: Encouraging Private Sector Engagement in Affordable Housing. Alberta, Canada: University of Calgary.

World Bank (2018). Myanmar Economic Monitor (MEM). Nay Pyi Taw: World Bank.

—. (1993). Housing Enabling Markets to Work. Washington DC: World Bank.

Yangon City Development Committee (YCDC) (2017). Building Permission Register. Yangon: Unpublished.

. (2016). Internal Annual Report. Yangon: YCDC. . (2010). Yearly Recorded Internal Database. Yangon: Unpublished.

YCDC and JICA (2014). A Strategic Urban Development Plan of Greater Yangon. Yangon: JICA.

Yangon Regional Government (2017). Report for Registered Squatter Population List. Yangon: Unpublished.

Yap, K.S. (2016). The enabling strategy and its discontent: Low-income housing policies and practices in Asia. Habitat International, 54: 166-172. https://doi. org/10.1016/j.habitatint.2015.11.026. 